\title{
Study on the Feasible Path of Specialty Setting and Curriculum Reform in Guangdong Private Higher Vocational Colleges
}

\author{
Yunli Cheng \\ Guangzhou Nanyang Polytechnic, Guangzhou 510925, China \\ 767220031@qq.com
}

Keywords: Professional system, curriculum reform, integration innovation, path research

\begin{abstract}
The relationship between education and the economy has injected new meaning into the times. Combining the status and role of private higher vocational colleges in Guangdong's economic transformation and industrial upgrading, how to actively adjust and flexibly set the profession according to the needs of local economic development has become the bottleneck of professional construction and curriculum reform in Guangdong private higher vocational colleges. . First of all, adhere to the development concept of "cross-border development of production and education, school and enterprise precision education", actively carry out the reform of the "step-type, multi-platform engineering and learning" talent training mode, and vigorously promote the four deep integration of school education and enterprise employment. The second is to optimize the curriculum system, give full play to regional advantages, and use regional resources to build a new generation of information technology professional system that integrates everything, integrates innovation and intelligent collaboration. Practice shows that vocational education and regional industry docking, combined with the needs of economic development, and actively adjust the flexible setting of professional, in order to better build Guangdong, Hong Kong and Macao Dawan District, the construction of the Belt and Road, for the Guangdong Province to achieve "four in the forefront of the country" Provide strong support. This is also the only way for the transformation and development of private higher vocational colleges in Guangdong.
\end{abstract}

\section{Introduction}

The relationship between education and the economy has injected new meaning into the times. The level and status of any higher vocational college depends on its level of professional construction. Whether the needs of higher vocational education and economic and social development are adapted, and the degree of adaptation is ultimately reflected in professional construction. Aiming at the needs of local economic development, active adjustment and flexible setting of majors are the embodiment of higher vocational education.

In this context, the core of the construction of higher vocational colleges is professional construction, and the focus of professional construction is on curriculum construction. The new generation of information technology industry is the key area for the promotion of China's strategic emerging industries during the 13th Five-Year Plan period. A new generation of information technology industry represented by mobile Internet, cloud computing, big data, artificial intelligence, etc. is rapidly emerging. Guangdong private higher vocational colleges need to vigorously promote the deep integration of school education and enterprise personnel, deep integration of skills training and academic qualifications. The deep integration of general education and the second classroom activities, the deep integration of professional teaching and ideological education, the optimization of the curriculum system, the reform of teaching content, the cultivation and condensing of professional characteristics, for the construction of Guangdong, Hong Kong and Macao Dawan District, the construction of the Belt and Road, China manufacturing 2025 high Quality innovative talents and technical skills talents provide strong support for Guangdong Province to achieve "four in the forefront of the country". 


\section{The Position and Role of Private Higher Vocational Colleges in Guangdong's Economic Transformation and Industrial Upgrading}

The relationship between education and economy has injected new connotation of the times. The level and status of any higher vocational college depends on the level of its professional construction. Whether the higher vocational education is adaptable to the demand for economic and social development and the degree of adaptation, it will finally be embodied through the professional construction. In view of the needs of local economic development, actively adjusting and flexibly setting up specialties are the embodiment of the characteristics of higher vocational education.

Higher vocational education and regional economic development of high relevance, as a whole, will form a mutual adjustment relationship, in constant interaction to achieve common development. The connection between vocational education and regional industry is regarded as a symbol of the formation and characteristic development of regional vocational education. To some extent, regional economy is defined by industrial characteristics and industrial advantages. Higher vocational education serves the development of regional economy and is born in the demand of regional industry. How to further strengthen professional construction, adjust professional structure, improve the quality of talent training, enhance the pertinence and applicability of talent training, and realize the docking of talents training with industry, industry and professional post, and promote the full employment of graduates has become the current reform and development of Higher Vocational Education in China.

It can be seen that the transformation of higher vocational colleges is a major event in China's education and an inevitable choice for education development. To give full play to the role of Vocational Education in promoting national and regional economic development, to play the role of Higher Vocational Colleges in the strategy of rejuvenating the country by science and education, to play the role of Higher Vocational Colleges in promoting scientific and technological progress, personnel training and economic society, and to give full play to the comprehensive national strength of high vocational schools in our country. The role is of great significance.

\section{The Study of the Overall Framework and Main Contents}

At present, the frontier technology represented by cloud computing, Internet of things, artificial intelligence, and virtual reality and so on is rising rapidly. A new generation of information technology is applied to the industry, which will vigorously promote the transformation and upgrading of traditional industries to build a new generation of information technology industry system, which is all interconnected, integrated, innovative, intelligent and safe and controllable.

\subsection{The overall framework of research}

Higher vocational colleges are the main suppliers of high skilled talents in the information technology industry. The most important thing is to optimize its own professional school structure first, by setting up and building a professional structure with distinctive features of higher vocational education, close to the pulse of economic and social development, closely following the pace of industrial structure adjustment, in accordance with the needs of industrial development and talent specifications in the economic and social development, around the emerging industries in the region. And the pillar industry as the core of the industrial chain, strive to create a professional chain, the formation of Higher Vocational Colleges and regional economic development path. The overall framework of the study is shown in Fig. 1 below: 


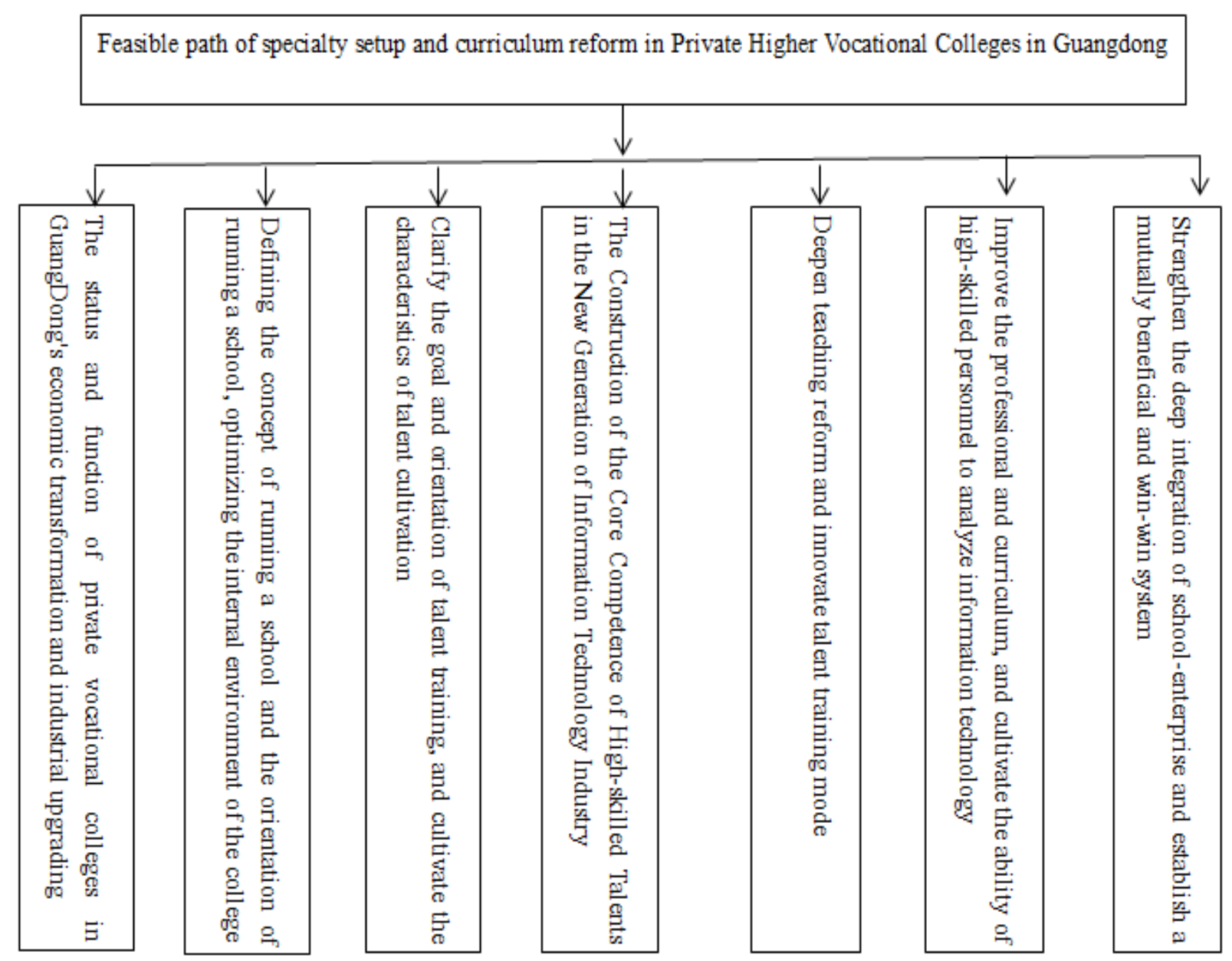

\subsection{Research content}

Fig. 1 Research Framework

3.2.1 To serve the regional economic and social development and industrial development, and clearly define the orientation of personnel training.

To fully understand the new trend and new requirements in the economic and social development of the country and the region, adhere to the concept of "the development of cross boundary development, the precise education of school and enterprise", and the training target of the "talent and talent and ability, outstanding ability and comprehensive development" in the school, and actively carry out the training mode of "step type, multi-platform engineering alternation" The reform, whether it is the integration and optimization of the existing specialties, or the new specialty, must clear the professional (professional direction) to the high-tech industry, the advanced manufacturing industry, the modern service industry and the dominant traditional industries, including the key industries and pillar industries, and the professional analysis of the butt industry. In order to grasp the importance of professional ability training, we should strive to achieve precise docking, precise education, and improve the quality and level of professional personnel training.

3.2.2 Promote the deep integration of production and education, and innovate the training mode of talents.

In accordance with the training target of professional talents, build up a cooperative education platform for school enterprise; grasp the 6 docking of professional setting and industrial development, curriculum content and professional standard, teaching process and production process, diploma and vocational qualification certificate, skill training and education promotion, vocational education and lifelong education; build and promote the "school" "Theoretical teaching + experimental training" + "professional cognition, post cognition, on post study, post internship, post internship, graduation thesis / design" + innovation and entrepreneurship education and employment + second classroom activities "the" ladder 
type, multi-platform engineering alternation "personnel training mode reform, improve the quality of talent cultivation, cultivation and practice. Professional features.

3.2.3 Adhere to the orientation of occupation (post) standards, and build "platform + module" curriculum system.

According to the principle of "the docking of curriculum content and professional standards, the docking of teaching process and production process", the curriculum system of "platform + module" is constructed, which takes students as the center, and trains students' professional ability as the main line, and joint industry enterprises develop and set up courses jointly. According to the requirements of the professional core skills and innovative entrepreneurship competitions, the curriculum system should be explicitly included in the relevant vocational qualification examination and skill competition training projects, and develop the course group of "class, certificate, competition and creation", and improve the students' professional ability and professional qualification certificate.

3.2.4 Push the technology of animal networking, cloud computing and artificial intelligence to integrate and infiltrate all the specialties.

The new generation of information technology is the third generation information technology architecture represented by the Internet of things, cloud computing, large data, artificial intelligence and so on. It is the fastest, most powerful and widely used high-tech technology in the history of human history. It puts forward new challenges to the ability of high skilled personnel, and puts forward the training path of high skill talents for a new generation of information technology industry: that is to strengthen the top-level design of high skilled personnel training system, perfect the specialty and curriculum setting, create a creative atmosphere, deepen the cooperation of school and enterprise and so on, and build professional talent cultivation. Foster mode. The new generation of information technology industry is an industry of intelligence intensive, high technology penetration and innovation driven. Information productivity is a new productive force. The intelligence of information technology talents is the inherent guarantee of promoting the development of industrial transformation.

3.2.5 Improve the innovation and entrepreneurship education system and cultivate students' innovative spirit and entrepreneurial ability.

The innovation and entrepreneurship education should cultivate the students' innovative spirit and entrepreneurial consciousness. On the basis of cultivating the students' innovative and entrepreneurial thinking, spirit and consciousness, the students can stimulate the students' potential for innovation and entrepreneurship. Actively explore and practice the full chain innovative entrepreneurial talent training model based on "Internet +", "professional +" awareness and value education, ability and quality education, practice and training education, real war and incubating education, and integrate innovative entrepreneurship education curriculum into professional training program.

3.2.6 Build a collaborative education platform to enhance the cultivation of professional characteristics.

The training work of "order class" and "modern apprenticeship" is the main task to promote the construction of key professional and brand specialty, public experimental training center and professional experimental training center, studio, and college students' practical teaching base. In accordance with the development concept of "production and teaching cross boundary development, school enterprise precision educating people", the education platform of "cooperation between school and enterprise, cooperation and win-win" is constructed, and the reform of talent training mode of "step type and multi-platform engineering alternation" is promoted, and professional characteristics are nurtured and condensed.

\section{Research Methods and Routes}

\subsection{Research methods}

The main research methods of the subject are literature research, interview, comparative research, field investigation, case analysis, experience summary. 


\subsection{Research route}

The research process of the professional setting and curriculum reform of private vocational colleges in Guangdong is divided into three stages, namely, the preparatory stage, the project implementation stage and the end of the project. The research roadmap is shown in Fig. 2 below:

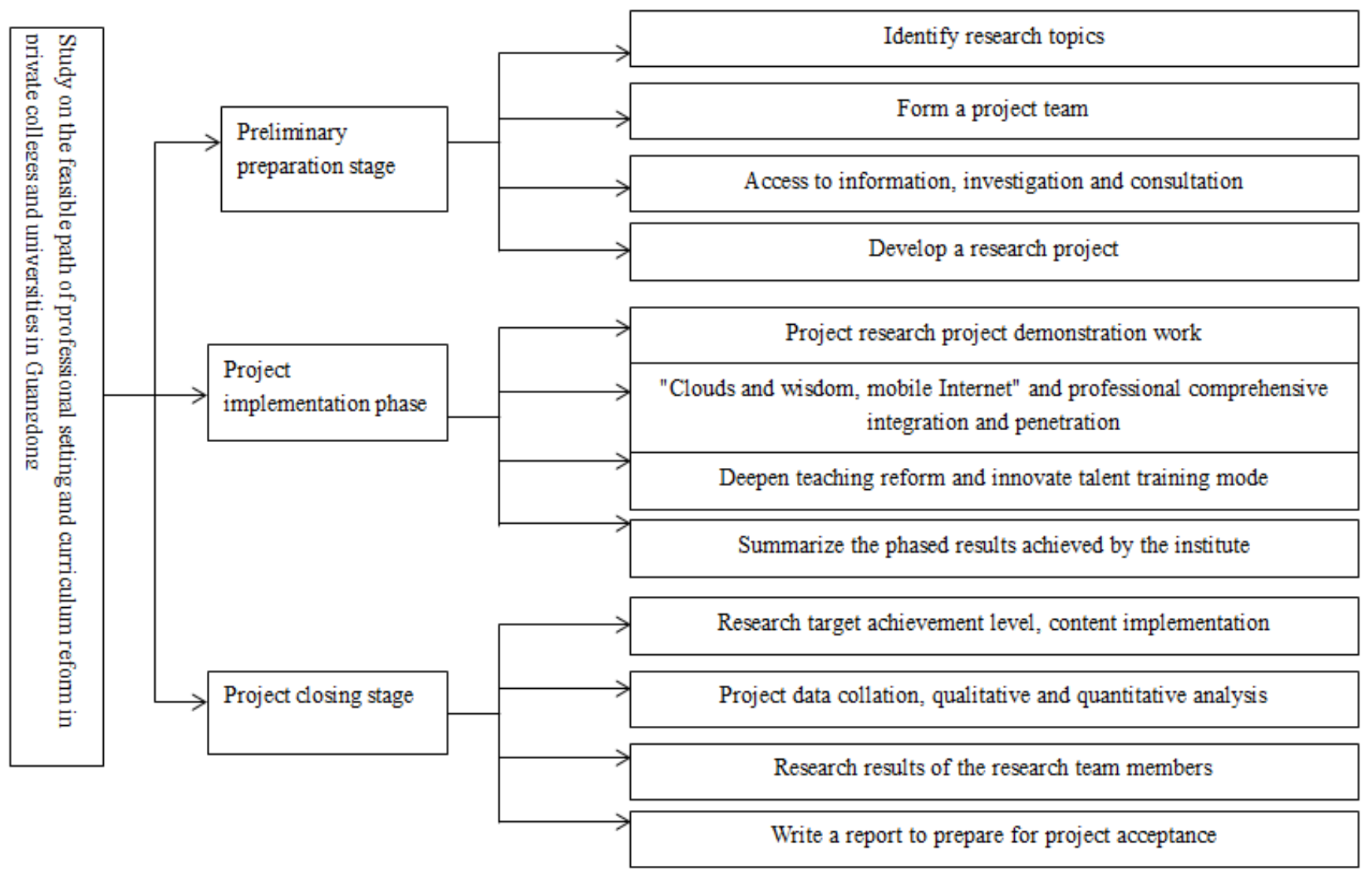

Fig. 2 Research Roadmap

\section{Conclusions}

China's Higher Vocational and technical education has become an important force in Higher Education from the edge to the center. The top level design of higher vocational education is the guiding ideology of running a school, and it is the soul. The core concept of higher vocational education is embodied in the guiding ideology of "taking service as the purpose, taking employment as the guidance, taking the road of combining production, learning and research". The purpose of the service is to set up and build the specialty on the needs of the economic growth point and the industry enterprise, around the needs of the strategic emerging industries and markets. Taking employment as the guidance is to set up courses, carry out learning activities and innovate the education of entrepreneurship around the requirements of professional posts, and the combination of production, learning and research has given higher vocational colleges a specific way to achieve the goal of running a school.

\section{Acknowledgment}

1. This article is the phased research result of the "Innovative Research on the Collaborative Talent Cultivation Model of Computer Application Technology Based on the Deep Integration of Schools and Enterprises” (Guangdong Nanyang Polytechnic) 2017 Innovation Strong School Project (Project No. NY-2017CQ1JGYB-03).

2. This is the phased research result of the "Study on the Feasible Path of Professional Setting and Curriculum Reform in Guangdong Private Higher Vocational Colleges” (Project No. 
2017GWZDXM004-08), a sub-project of the Major Research (Applied Research) Project of Guangdong Province in 2017.

\section{Reference}

[1]. Dong Xiaohui. Construction of the Training Model of Work-study Integration for Computer Application Technology Specialty in Higher Vocational Colleges. Contemporary Educational Practice and Teaching Research [J], 2015, (11)

[2]. Xu Lili, Liu QingPu. Discussion on the Curriculum System of Computer Specialty in Higher Vocational Colleges Based on Mobile Internet Application [J], Educational Technology Guide, 2017 (11)

[3]. Liu Xiao gang. Exploration of computer professional reform in Higher Vocational Education Based on mobile Internet. [J], 2017 (5)

[4]. Zhao Yue Wang. Research on the framework of modern vocational education system in Chongqing. Science consultation [J], 2015 (11)

[5]. Li Zhan Jun. A Comparative Study and Practice of the Construction of Teachers 'Teachers' Team in Secondary and New Vocational Education; Journal of Qingdao Vocational and Technical College [J], 2018 (4)

[6]. Gang Jian Jibe. Higher vocational talents training mode and its connotation analysis [J] Wuhan Polytechnic, 2017 (10)

[7]. Li Yapping. Summary of theoretical research on undergraduate training mode in Higher Education in China [J], 2016 (8) in Jiangsu higher education

[8] Yun Qiu. Analysis on new enterprise marketing modes under the electronic business environment[A]. Proceedings of 2016 International Conference on Communication Technology and System ( ICCTS 2016) [C]. 2016 